\title{
Politics and Media Hegemony Policy in Indonesia
}

\author{
http://dx.doi.org/10.25008/jkiski.v6i2.556 \\ Erman Anom $^{*}$, Hamdani M. Syam², Nur Anisah ${ }^{3}$, Dafrizal Samsudin $^{4}$ \\ ${ }^{1}$ Faculty of Communication, Universitas Esa Unggul \\ J1. Arjuna Utara No. 9. Tol Tomang Kebun Jeruk, Jakarta 11510 - Indonesia \\ ${ }^{2,3}$ Department of Communications, Universitas Syiah Kuala \\ J1. T. Nyak Arief Darussalam, Banda Aceh 23111 - Indonesia \\ ${ }^{4}$ Faculty of Communications, Universitas Islam Riau \\ Jl. Kaharuddin Nasution 113 Pekanbaru 28284, Riau - Indonesia \\ *Corresponding author: erman.anom@esaunggul.ac.id
}

Submitted: August 12, 2021, Revised: September 15, 2021, Accepted: November 30, 2021

Accredited by Kemristekdikti No. 28/E/KPT/2019

\begin{abstract}
This research aims to help those trying to master the media and political power in Indonesia and use the media as a tool to build community system from the Dutch colonial rule to the independence era, particularly from 1999 to 2019. This study is about how the system formed the media under the political policy until it developed into a base media in Indonesia between the era of the Dutch conquest and the year 2019. To achieve the objective of the study, investigation has been made upon media as a factor that affects the formation of the base to control the freedom of the media by using the investigation approach on history through document analysis and deep interview. The finding shows that forming a base that controls the freedom of the media is based on a proses which is designed soberly to fit with the philosophy and the value which is practiced by the ruling leader, and became the base of the national media activist in Indonesia.
\end{abstract}

Keywords: Politics and media; media policy; media hegemony; ruling government; power and hegemony

\section{Introduction}

To run the wheel of the ruling government to control the media is divided into several periods. This study separates government power and hegemony towards the media in a couple of timelines, namely the Dutch era, Japanese, Soekarno, Soeharto and the era from 1999-2019.

In strengthening the hegemony, the government that is in control of Indonesia always controls the freedom of the media. In the world of media, controlling is summarized in the concept of rules dan amendments which are always made. Media in their activity has an obligation to defend, support, and execute their governments order.

In media's activity in Indonesia, the use of ideology must be able to support the regime in order to strengthen the political power for their development in economic, political, social, and cultural fields. This can be seen from the system of controlling the media in the country which is connected with the Indonesian government by running the politics and policy of controlling the media. 
Basically, the media systems are different from one country to another. But the difference does not implicate that one is better than the other. Merrill (1971) said that the Press system is reflected on the political system which is in a related nation.

It cannot be denied that the media is currently developing rapidly due to the advanced media technology. The progress of media obeys the role which leads to a rising of a nation. This is also happening to the Indonesian media, which becomes a tool in the development of a nation and is very important to the life of Indonesian people and the freedom of the media is always in control of the policy and politics. Arifin (1992) said that Indonesia has used the media as a tool for development. Even the government of other developing countries too doesn't miss the opportunity to use the media to push the economic development in their country.

Based on the description above, the research problem are as follows; does the media have a role in giving support to develop their government hegemony in the era of their leadership; does the government use the media as a tool to strengthen the political hegemony; how does the Indonesian government design a foundation to control the freedom of the media.

\section{Theoretical Framework}

Iain Mclean (1996) explained hegemony originated from a Greek word hegemon which means chieftain (a leader to a community or group). Siahan (2001) argue hegemony is a denial of a critical thinking of the people to leader (authority holder, military, intellectual, ideology and religion) to hold his power through a language discourse systematically, directed and ongoing, until the people can accept the idea of a regime voluntarily.

William I. Robinson (1996), said that Gramsci theory about the meaning of hegemony can be connected as a concept of relation between the peoples living class that is a more dominant class will monopole the lower class from an economic, cultural and morale perspective. Other public's class will give an approval spontaneously without any pressure or force towards the dominant class of hegemony. This is because the dominant class or a certain group is a hegemony power which is able to control and influence certain classes and groups. In other word, Gramsci saw hegemony as a concept that illustrates a connection that has a monopoly characteristic and dominate between the classes of public's leader and their subordinate in a country.

Stephen Gill (1990) argued that hegemony power is a power that is dominant in a system of government among countries and has unmatched ability with other countries as seen from the weapon industry and economical perspective. Again, according to Gill, hegemony power is something that is well connected with actions whether it is measured empirically. In other words, Gill interpreted hegemony power as a country that has an advantage on the economical and military perspective that is definitely doing the elements of domination and monopoly that is the same as a salesman monopoly that dominates the small market.

Roger Simons (2000), Gramsci uses the word leadership briefing consecutively with hegemony and opposite with dominant. The use of the word hegemony in the meaning according to Gramsci must be differentiated from the original meaning in Greek word that is the conquest of a nation over another. The term hegemony is first used by Plekhanov in the year 1880 to show the need of the working class to build a unity with the farmers with the point of destroying the tyrant regime.

Antonio Gramsci quoted in the writing of history and culture translated The Prison Notebooks (2000), used the term hegemony to refer to the rulers ideology. The hegemony theory less focuses on the factor of economy and structural ideology that favor a certain class, but more to press ideology itself, form of expression, how to apply, and the mechanism that has to be done to defend and develop itself to form a natural thinking. According to Gramsci, lasting power requires a working system in the form of violence that is forceful and soft, and persuasive as well.

To conserve power, domination must be applied and sooner get replaced by hegemony. Hegemony's purpose is to validate the ruler and the social inequality which is caused by the power itself. If hegemony is reached, the ruler doesn't have to always oppress because the oppressed will receive a status quo. They are persuaded to not again see the presence of inequality that is harmful to them, or see it as something normal, natural, even fair and that it corresponds to Divines Will. Gramsci also said that hegemony is formed through several ways and through different places of daily lives which seem to not be as serious, haunted, and political. 
Antonio Gramsci (in Eriyanto 2001), argued that capitalist domination power doesn't always come through economical means and production relations, but also power and hegemony. Gramsci built a theory which emphasizes about a group's acceptance towards domination in the presence of a dominant group in a peaceful process, without any act of violence. Media can be a tool where a group strengthens its position and lowers another group's.

Raymond Williams (in Arthur Arsa berger 1991), said that hegemony works on two channels: ideology and culture where the values itself works. Through hegemony, a dominant groups ideology can be spread, value and trust can be contagious. However, it is different from manipulation or indoctrination, hegemony precisely seems normal, people accept it for its normality and voluntarily.

Ariel Heryanti (1999) said power of hegemony in Gramsci version mentions that hegemony gives tolerance to difference and even resistance, even to a certain extent, as far as the ruler's power. Therefore, the oppressed is hoped to feel happy and hope for a change even if still overpowered. Hegemony is not just a characteristic that relents to the enemy's wishes, but also holding self to not just fight for self-importance vulgarly. What is needed is a packaging. Self-need is wrapped in other interests, as if it represented a public interest.

In the politics records (2001), Gramsci said that hegemony is a class and the members run the power to all the class below them with violence and persuasion. Hegemony isn't a domination relation using power, but a relation approval by using politics leadership and ideology. Hegemony is a consensus organization. Gramsci denied economics, and insisted there to be independency of ideology from economical determinism and mass media in the mean of a one-point ideology struggle, is one of the effects in Gramsci point of view. The standing point of Gramsci that denied economics appears because he sought the struggle to build an ideological hegemony is the main factor in a radical change. Fiske (1992), said that hegemony always put contradiction constantly between ideology and oppressed peoples experience which made it always a field of ideological struggle.

Lenin, by Roger Simon (2000), said that hegemony is a strategy to revolution, a strategy that has to be done by the working class and the members to reach a major support.

\section{The Policy}

The concept of policy and system are two concepts that are dependent on one another (Asiah Sarji 1996). System emphasizes relation, purpose, and proses between relation that is intertwined, and will always be social, there is also time where the policy makers emphasize how to achieve purpose for each of the elements which is given a function in every institution relation which is complex dan dependent on one another (McDonnell 1984). With the same intention, Negel (1988) is detailing a definition as an amendment, decision, choice, project and program. If only policy is accepted as a way to reach a goal, system is then a tool to organize to reach the only purpose or goal (Asiah Sarji 1996). Because of that identification proses is a function for every component is one system and should be considered by Clarke and White (1989) as an important thing. Even though the policy concept is wide, the assessment like Mayer and Greenwood (1980), Hancock (1981), Ekecrantz (1984), and Wan Azmi Ramli (1982) is more likely to accept a policy concept as a formation and the termination that is made to reach a goal in an organization.

Even though the policy may be a politic reality (Hancock 1981:77), it was formed and succeeded from scarcity about philosophy and social structure where an environment is suitable for the policy to happen. In this context, there is a strong connection between policy and system that is easier to explain. This is because according to Ekectrantz (1984), formation and termination of a policy is a member's role in a system and is very certain to be known. This is because according to Sztompka (1974), Masco (1984), and Direnzo (1977), system itself depends on the surroundings.

\section{Political System}

Dahl (1978) formulates that politics system is a pattern about human relation that covers widely, surveillance, effects, power or authority. Democracy and dictatorship are political system. Both those politic contradict one another. Democracy is a political system where the case of opportunity to participate in a formation of many decisions given by local adults. On the other hand, dictatorship is a political system, where the case of opportunity to participate in a decision making.

While Easton (1965) formulates a political system as life of politic holds all kinds of activity that affects a policy from the 
authority side, and is accepted for the people and affects the way to run the policy. Machiavelli interpreted a politics concept that is quite dramatic. According to Belion, the people are a big stage that on top of it lies a contention between hero and not a hero, the shape of the movement is to be run and ruled (Duncan 1962). To Harris (1976), politics isn't just an element that contains difference, though to press the aspects of similarity that is formed in between two or more participants in the proses of politics, the step that must be taken is to make sure that the conflict can be managed.

The political system meaning that is various can be understood because the term of politics has many different meanings. Miriam Budiarjo (2001) said that politics do cover many activities in a country that involves the determination of goals and the execution of the goals that is why politics involves a country, power, decision making, policy and division. While Rush (1986) admitted that power can be seen as a base point so that the proses of a politic is a line of events that has a connection between one another that is based on power. Referring to Lasswell (1965) politics is a technique to run power, or a problem in doing and controlling a power, or politic is a struggle to achieve and share power, that is whoever receives it, how and why.

\section{Media System}

The meaning of media is a presumption to various and specific symptoms, the few and the many is connected, between the whole and the surroundings. System is a bunch of objects that interacts to reach a certain goal. System is an overall attitude, behavior and its position that aim to affect the content, process and impact from government policy.

According to Athey (1982), system is a set of components or parts that can be seen as a teamwork that can reach a goal as a whole. In this context, according to Cleland and King (1972), a system is able to show a structure and parts (subsystem) which has small parts (sub-subsystem) that explain a whole system. Besides, a system has component characteristic, connected to and dependent on each other, and show a structure, and then form a set of a whole system, and it also has a limit that differentiate a system with its surroundings (Asiah Sarji 1996).

\section{Material and Methodology}

In doing this research, the writer used an investigation approach through document analysis and deep interview, while data was obtained, analyzed, interpreted according to the phenomena that becomes a base of the research. The technique for this investigation used thorough interview and document analysis methods is hoped to be able to illustrate the activity of controlling the media in Indonesia.

In this investigation approach, the researcher used: deep interview and document analysis methods. In the interview research, the researcher interviewed an editor-in-chief and an official of the Ministry of Communication and Informatics of the Republic of Indonesia as well as political figures.

\section{Result and Discussion}

Since the proclamation of independence of the Republic of Indonesia on $17^{\text {th }}$ August 1945, Indonesia has experienced a change in form of state a few times, that is the Republic of Indonesia in 1945, the United Republic of Indonesia (RIS) formed federally on $27^{\text {th }}$ December 1949, and then in August 1950, RIS changed to only the Republic of Indonesia (RI) formed on a unity and the 2004 constitutional amendment of the Republic of Indonesia.

While politics and media policy in Indonesia has experienced 6 phases, including the Dutch colonial rule, the Japanese occupation, Soekarno's Old Order, Suharto's New Order and now the 1999-2019 reform era.

\section{The Dutch Colonial Rule 1856-1942}

In an interview with Arifin Harahap (2019), he said that the oldest Malaya based media is Bintang Surabaya (1861) and Perwata Soerabaya (1902). Arifin's comment is expressed as follows:

'media in nusantara... the oldest newspaper in Malaya is Bintang Surabaya (1865) $\ldots$ the people's movement and press are what is meritorious and develop the Indonesian concept'.

Otherwise, following Edward C. Smith (1969), the government held a surveillance upon Indonesia's media, Chinese, or the Dutch. One amendment made by the Dutch is 
about a severe punishment against broadcasting with words, mail or drawings, live or not, that is meant to screw up order and prosperity and push the fall of Indian Dutch. According to Swantoro and Atmakusumah (2002), on $7^{\text {th }}$ September 1931 the Dutch colony introduced press ordinances. Under the ordinance the governor general has the right to prohibit a certain publishing of which value can interfere in the public order.

At the time of Dutch-East India, rules about media have been adjusted to the amendment in the year 1856 about publishing stuff and also to the amendment of 1906. The difference between these amendments is that first has a shriveling and preventions attitude, while the second has an oppression attitude (Abd. Surjomiharjo, 2002).

In RR $1856\left(\mathrm{~KB}\right.$ April $8^{\text {th }} 1856$ ind.stb.no.74) in other word said: all printed works before being published, one script must be sent first to the head of the local authority that is justice official. The shipping must be done by a publisher and must be signed. Next is the sensing that was done in the year 1906 (KB 19 Mac 106 ind.stb.no.270) has set that the removal of a certain amendment that is preventive, until the surrendering of the script to the government official can be done in a 24 timeline after the goods is spread.

During the Dutch colony, media was used for colonial purpose, while the fighters of Indonesian freedom spread their aspirations through media. Media is a tool that is feared by the Dutch colonial ruler so that the control of media was done pretty tightly.

Basically, the policy that was done by the government during the Dutch colonial rule, in fact a few authorities revoking few licenses of media is one of the characteristics that sticks out. The authority reason is to keep the public's safety, by using the amendment of 1856 that has a preventive attitude, the amendment of 1906 that has an oppressive attitude, and the ordaining amendment of 1931 which is about a withdrawal of the medias licenses and must report few good news to the printing media.

\section{The Japanese Occupation 1942-1945}

During this Japanese occupation. Indonesian media was used as a tool to mobilize the mass to reach the Japanese goal. In this era, Indonesian media experienced a progress from a technical perspective, but the licenses of the publishing as a tool to control the ruler of Japanese is introduced. The JavaMadura ruler controlled the publishing and communication tool with the amendment no.16/1942 has two articles and it is the licenses to publish and screening prevention. Article 1 said that even all printing goods must have a permit to publish. Article two prohibited all publishing that before all this is enemy to Japanese, to continue his publishing (Swantoro and Atmakusumah, 2002).

During the Japanese occupation. Java and Madura were under the rule of Balatentera $\mathrm{XVI}$, Sumatera is given to Balatentera XXV, and the other region (Kalimatan, Sulawesi, Maluku and Nusa Tenggara) are under the rule of the Japanese navy. Although it is not stated explicitly, but it is clear enough that publishing that is forbidden covers all the Dutch's media, Indonesia's media that is anti-Japan, and also Chinese media that attacked Japan that brutalize Chinese.

\section{Soekarno Era}

From 1945 to 1965 , the press itself was involved in opposition around the results of KMB (Round Table Conference) with the parties, both in Parliament and Cabinet. The atmosphere and political situation at that particular time was written and preached in the title, caricature and press corner.

The freedom of the press and publication must have a well-informed, both in economic, political, social and cultural fields, because without a clear purpose it will gradually have difficulties. Competition in this business world has a heavy competitor, especially in terms of equipment which is still far behind when compared with printing equipment owned by the Dutch and Chinese, that are supported by strong capital. In this liberal era, the press is free to preach and provide information to the community. Meanwhile, in the era of the Soekarno, the press became a funnel of Soekarno, the press was controlled by Soekarno in accordance with the political direction he was involved.

\section{Soeharto Era}


Press Pancasila is known in the era of New Order (Orde Baru) Soeharto. There was a term SIUPP (Press Issuance Business License) and a letter of publication (SIT) under the auspices of the Minister of Information or Ministry of Information. At this time, journalists and press that did not cooperate with the government in disseminating the news to the wider community is considered to have unsettling and divisive between the government and the people, leaders with the people, and so forth. Therefore, revocation of SIUPP or SIT will be carried out at press companies deemed to have violated certain provisions. In fact, there was Press Law no. 11/1966 and Press Law no. 21/1982 which are the refinement of the continuation of the Law No $11 / 1966$. This Press Law is strengthened by the policy Law (UUD) 1945 Article 28, which is the independence of the company and the assembly, expressing thoughts and writings etc, which are stipulated by the law.

Presidential Decree No. 5 of 1985 which declared February 5 as the National Press Day is to encourage the press to cooperate more with the Government in educating the people to achieve the national goals of the Indonesian nation. The relationship between the press and the people is the most important element in running the wheel of development so that the NKRI (Unitary State of the Republic of Indonesia) remains firm on earth with a spirit of unity, without being torn apart by the news that are able to divide the unity that has been established.

The freedom of the press in the era of Soeharto which is known as Pancasila Press seemed to imply free press but freedom at certain boundaries that had been governed by the Government. In other words, the press is still tied to all the rules that the New Order (Orde Baru) government would have better, more directed and more accountable in its reporting.

During Soeharto's government, Pancasila as the state ideology became the foundation of its policy in creating and controlling media. Thus, all matters related to the media system must be returned to constitutional foundation, which is Pancasila.

President Soeharto's speech at the opening of the Conference of XVI Association of Indonesian Journalists in Padang, West Sumatera, 4 December 1978, said:

“... development press is directed towards attitudes and behaviors that are being imbued by Pancasila.... In this moment, one important step is the press efforts that continuously implement the Guidelines for the Passion and Practice of Pancasila (P4) in accordance with the decree of the MPR No. II/MPR/1978".

Suharto's policy on newspapers was not detached from the article 28 of 1945 Constitution, decree of the Temporary People's Consultative Council (MPRS) No. XXXII/MPRS/1966, MPR Decree No. IV/MPR/1973 on GBHN regarding good newspaper which is free and responsible. The press of Pancasila as the press system in the Soeharto era is the power holder and executor of the points stipulated in the Act. Based on the article 28 of the 1945 Constitution, the press system was formed and summarized in the concept of free and responsible newspaper.

In an interview with Asep Saifuddin (2019), he said the principles and the guidance of development press in Suharto's leadership could be seen from the aspect of 1945 Constitution, MPR Decree, GBHN, the Press Basic Act, values that apply to Indonesia society, Code of Professional Ethics. According to ASEP Saifuddin:

\section{“...Soeharto's Press Foundation is essentially the Constitution 1945, the decree of the People's Consultative Assembly, the Outline of State Direction, the Press Basic Act, the Journalistic Code of Ethics, cultural values..."}

From that perspective, there are two aspects that are closely related to freedom and responsibility, namely the law and the ethics. Legally, it can be seen in the explanation of Act No. 11/1966 which was amended by Act No. 4/1967 and amended again by Act No. $21 / 1982$ on the provisions of the press principle asserted as follows:

"In the press principles are listed about freedom of the press which is closely 
related to the necessity of accountability to the Almighty God, the interests of the people and the safety of the state, the continuity and completion of national struggle, moral, ethics and accountability to the personality of the Nation ".

In the Journalistic Code of Ethics, the issue of accountability is detailed, as follows: (1) Indonesian journalists responsibly and wisely consider the appropriateness of news, writings, drawings, and caricatures and so on to be broadcast; (2) Indonesian journalists do not broadcast: Things that are destructive to and can harm the country and nation, Things that cause chaos, Things that can offend the moral, religion, beliefs or faith of a person or group of persons which are protected by law; (3) Indonesian journalists do their work based on responsible freedom for the public safety. They must not misuse their position and ability to their own interests/or interests of the group; (4) Indonesian journalists prioritize Indonesian national interest in carrying out their journalistic duties concerning the nation and other countries.

During the Grand Meeting of Chief Author and Indonesian Journalists Association on February 9 at the State Palace, President Soeharto said in his welcoming speech:

"... In developing a direction towards more mature growth, I think that it is very urgent to develop developmental press. With regard to our determination to build on our personality, our national press development should be built on our personality, by digging our own experiences and with the necessities of our own national development. This means that the developmental press should drive the modernization of our society that continues to thrive on the sublime values of the nation's culture. "

\section{The Era of 1999-2019}

The press law No. 40/1999 has been enacted as a press policy in the era of 19992019 , but in reality, the press always complies with it when facing the Court of Justice which always uses KUHP instead of the Press Act
No. 40/1999. The Press Council cannot do much, so that many press agencies have established their own legal institution (Ombudsman) to defend their interests in the Court of Justice that still uses the KHUP to ensnare the press in any of the issues related to the press.

The freedom of the press wants to be born freely without any ties or restrictions from any party, neither the government, political parties, nor security. However, the freedom of the press should have a boundary as social responsibility to the community in its more professional and responsible reporting. The press should also be aware of the news which does not cause unrest or division in society which is detrimental to national stability. The Indonesian press freedom is the freedom of the responsible press which is in the discretion of Pancasila values. Each reporting is not allowed to carry "SARA" (tribal, religious, racial, and societal group) issues which will ultimately cause unrest in society and ruin the unity of the Indonesia nation. The guaranteed press independence will revive the wheels of the democracy agency that has been less functional.

In an interview with Arifin Harahap (2019), he said the media foundation of the 1999-2019 era is based on the law. Arifin's comment can be expressed as follows:

"... 1999-2019 Media Foundation on Press Law No. 40 year 1999... Media people often work in making news and broadcast news based on referrals in accordance with existing laws......."

\section{Conclusion}

In the era of each government that governed Indonesia, the media became a member of Indonesian government which is the political principles and philosophy of the Indonesian nation. In this spirit, the institutions related to the media reside and work, so that the position of the media can be seen more clearly. Freedom and responsibility can be seen from its role in historical development. Media does not want to accentuate the conflict between freedom and power, apart from being more concerned on harmony, suitability, 
balance, cooperation and deliberation for mutual interest.

For the Government, the national ideology is the cornerstone of the policy in establishing the design of development media, not only the contents and containers as well as tools to achieve the goal of national and state life but is the foundation of the country, state ideology and also national goals. Thus, all the articles of the Constitution shall be returned to its essence namely Pancasila. Likewise, related to the media system, it must be returned to the Constitutional foundation of Pancasila.

Every government in Indonesia has a perspective on the media that should be healthy, free and responsible, and must have a journalistic code of ethics. Free but esponsible is the responsibility to the Almighty God, the interests of the people and the state safety, the continuity and completion of national struggle, moral and ethics as well as to the nation personality. In the journalistic code of ethics, responsible means journalists with a sense of responsibility and wise consider the worthiness of news, writings, drawings, caricatures and so on, and are not allowed to broadcast materials that are alluding to the ethics, religion, beliefs or faiths of a person or group of persons, in the journalistic related to nations and other countries, prioritizing Indonesia's national interests.

In the development of good, free and responsible media, the factors of cultural development and self-control in society are very important. Self-control must be embodied in oneself. Governments who govern the culture of self-control created and developed by way of kite playing. Sometimes it plays a positive role in stopping the desire that is too strict in control or to carry out strict control, and it also opens the opportunity to loosen up immediately after a political crisis harm can be addressed. Self-control is like kite playing develops in the community, especially in the media activities. In the activity of controlling media with kite-playing is guided by the concept of "responsible media freedom".

This study found that throughout the ruling tenure period, free and responsible media can be carried out well, if the media is materially good, economically healthy. Such Media can be a tool of struggle and partner of government. Thus the media activity was built and was given the ease to establish. Media needs to be healthy in terms of economics by not fading the spirit of community idealism, and is characterized by the opening of the freedom of information faucet.

Recognition discrepancy in the legislation of the Republic of Indonesia, is a kind of victory for the Indonesian press. Law No. 40, 1999, among other things, guarantees freedom of the press as well as recognize and guarantee the right to information and freedom of expressing thoughts and opinions in accordance with conscience as the most essential human rights.

\section{References}

Adam, A. W. (1999). Strategi sang komondan. Dim. M. Amien Rais (pnyt.). Jika rakyat berkuasa, 173-176.

Adorno, T. W. (1950). The authoritarian personality. New York: W. Norton.

Aminudin. (1999). Kekuatan Islam dan pergulatan kekuasaan di Indonesia sesudah runtuhnya rezim Soeharto. Jogyakarta: Pustaka Pelajar.

Arifin, A. (1992). Komunikasi politik dan pers Pancasila. Jakarta: Media Sejahtera.

Athey, T. H. (1982). Systemic system appproach: An intergrated method for solving systems problems. New Jersey: Sage.

Atmadi, T. (1982). Development of the Indonesian press and its system. Jakarta: The Indonesian Press.

Bagdikian, B. (1969). The press and its crisis of identity. Kansas. University Press of Kansas.

Batubara, C. (1982). Dwi Windu Orde Baru. Jakarta: BP ALDA.

Bellamy, R. (1987). Modern Italian social theory. From Pareto to the present. Translate. In Vedi R. Hadiz. Teori sosial modern: Perspektif Itali. 1990. Jakarta: LP3ES.

Bocock, R. (1986). Hegemony. England: Ellis Horwood Limited.

Bugin, B. (2001). Metodologi Penelitian Kualitatif. Jakarta. PT. Raja Grafindo Persada. 
Cohen, M. (1998). Acid test: the media corrode Suharto's legitimacy'. Far Eastern Economic Review, 28, 18-19.

Crouch, H. (1986). Militer dan Politik di Indonesia. Jakarta: PT. Sinar Harapan.

Fairclough, N. (2013). Critical discourse analysis: The critical study of language. Routledge.

Gaffar, A. (1999a). Demokrasi Indonesia masa lampau, kini dan mendatang. Surabaya. Makalah Diskusi AIPI.

Gaffar, A. (1999b). Politik Indonesia transisi menuju demokrasi. Jogyakarta: Pustaka Pelajar.

Gramsci, A. (1971). Selections form the Prision Notebook. Edited and translated by Quince Hoore \& Goffrey Nowell Smith. London: Lawrence and Wishart.

Green, M. (1995). Dari Soekarno ke Soeharto G30S/PKI. Jakarta: Pustaka Utama Grafiti.

Harahap, A. (2019). Politik dan Kebijakan hegemoni Media Di Indonesia. Jakarta. Interview 2019.

Hill, D. T. (1999). The Press in New Orde Indonesia. Needlands: University of Wesstern Australia Press.

Jensen, K., B. (2001). A Handbook of Media and Communication Research Qualitative and quantitative methodologies. London and New York: Routledge.

Kusumah, A. (1981). Kebebasan pers dan arus informasi di Indonesia. Jakarta: Lembaga Studi Pembangunan.

Lesmana, T. (1999). 33 Tahun 308/PKI Meluruskan Kembali Sejarah. $M$. Dawam Raharjo et al. Membuka Lipatan Sejarah Menguak Fakta Gerakan PKI. Jakarta: Pustaka Cidesindo.

Mas'oed, M. (1989). Ekonomi dan struktur politik Orde Baru 1966-1971. Jakarta. LP3ES.

Mayer, R. R., \& Greenwood, E. (1980). The design of social policy research. Englewood Cliffs, NJ: Prentice-Hall.

Merrill, J. C. (1971). The role of the mass media in national development: An open question for speculation. Gazette (Leiden, Netherlands), 17(4), 236-242.
Moleong, L. J. (2001). Metodologi Peneliti Kualitatif. Bandung: Remaja Rosda Karya.

Menon, V. (1999). Looking Back and Looking Ahead: The Press in Asean. Media Asia, 26(2), 100-104.

Purwoko, P. Sistem Politik dan Pemerintahan Indonesia Setelah Reformasi. Politika: Jurnal Ilmu Politik, 1(1), 104-117.

Razak, A. (1986). The General Characteristics of the Indonesian Press. Media Asia, 13(4), 218-225.

Roeder, O. G. (1969). Soeharto: dari pradjurit sampai presiden. Gunung Agung.

Romano, A. (1998). Normative theories of development journalism: State versus practitioner perspectives in Indonesia. Australian Journalism Review, 20(2), 60-87.

Saifuddin, A. (2019). Politik dan Kebijakan hegemoni Media Di Indonesia. Jakarta. Interview. 2019.

Sarji, A. (1996). Pengaruh persekitaran politik dan sosio budaya sistem penyiaran Malaysia dalam perkembangan penyiaran radio di Malaya dari tahun 1920-1959 (the influence of political surrounding and social cultural broadcasting system in Malaysia in the development of radio in Malaya from 1920-1959). Doctoral Dissertation. Bangi. Universiti Kebangsaan Malaysia.

Simon, R. (1991). Gramscis Political Thought: An Introduction. London: Lawrence and Wishart.

Surjomihardjo, A. (1980). Beberapa segi perkembangan sejarah pers di Indonesia. Proyek Penelitian Pengembangan Penerangan, Departemen Penerangan RI. 